\title{
TTERS
}

\section{BIRD HOUSES AND BIRD WATCHING}

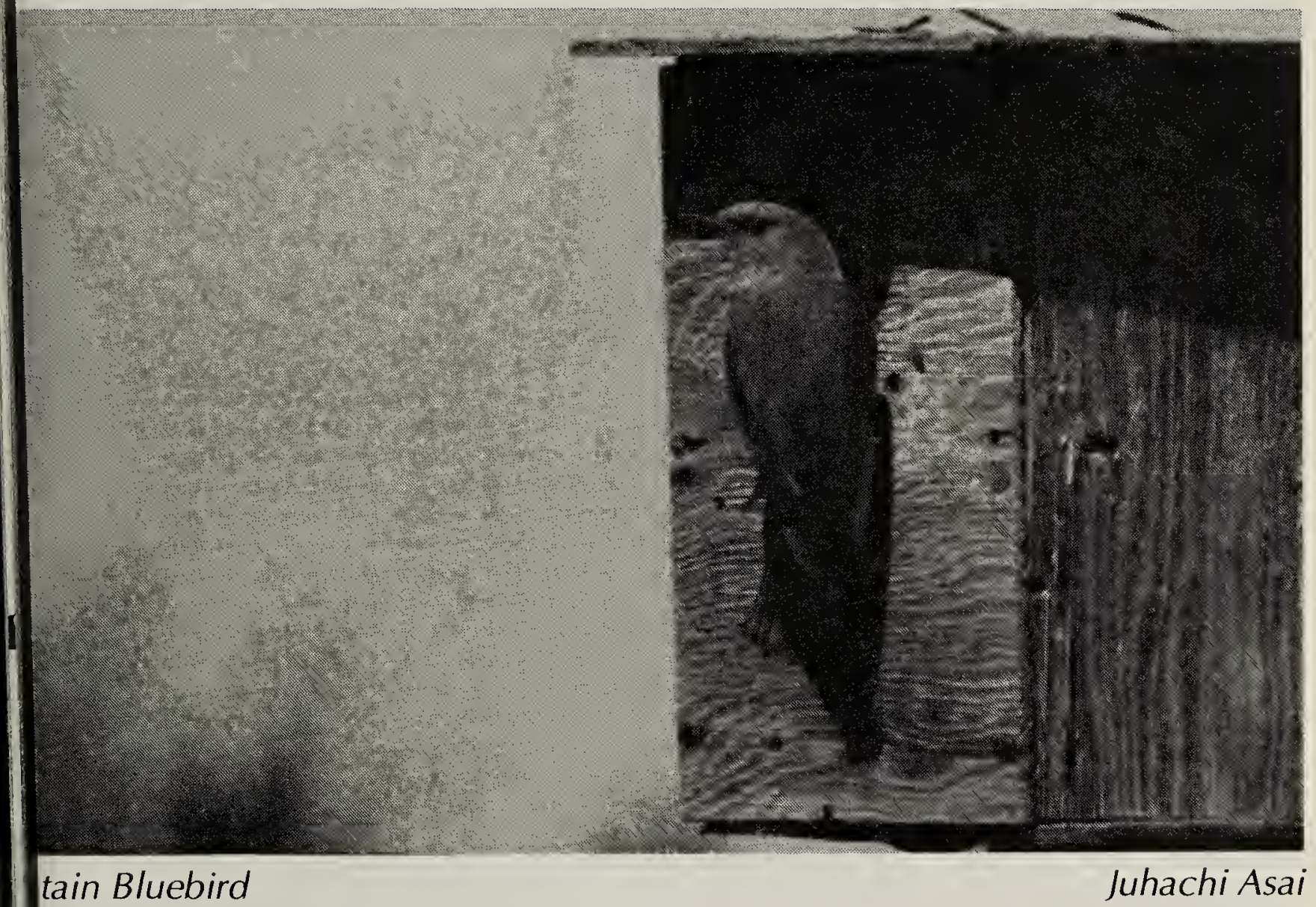

\section{EBIRD TRAILS}

vays enjoy reading articles on ain Bluebirds as my wife and I have with 300 houses which we started 0 . We have been banding since - Roger Johnson, Box 555. , Alberta. TOB 3SO

\section{BIRD HOUSES AND BIRD WATCHING}

Bird watching and building bird houses keeps me busy - no stress - no boredom. During winter I build bird houses and in summer I am busy checking them. I had a successful year in 1989. 
I have 286 houses along road sides and pastures. Of these, 186 were occupied by Tree Swallows, 54 by House Wrens and 12 by Mountain Bluebirds.. There were 8 with House Sparrows and 2 with field mice. Only 24 boxes were unoccupied. Some of those I had placed about 20 or 30 yards apart. Since Tree Swallows are territorial I had hoped bluebirds would occupy them, the swallows leaving the one nearer for the bluebirds. It has worked in some instnaces, but there are not enough bluebirds to go around. The overall occupancy rate in 1989 was almost $92 \%$.

The bluebirds had two hatches, the first with 5 or 6 eggs and the second with 3 or 4 eggs. Several friends put out a few boxes and each was able to attract a pair of bluebirds.

One House Wren laid a surprising eight eggs. All hatched. The box was full of gaping, hungry mouths! Mrs. Wren must not have known about the pill. At any rate, all eight left the nest successfully.

1 remember in the 1950s when Stuart and Mary Houston showed their slides in a nature talk to the Melville-Yorkton teachers' convention. I was one of the teachers present, although retired now.

My winter feeder is busy. I do my bird watching from my living room window. Chickadees, Downy and Hairy Woodpecker, an occasional Pine Grosbeak, but no redpolls this winter. - John M. Hicke, Box 291, Grayson, Saskatchewan. SOA $1 \mathrm{E} 0$

\section{AMERICAN KESTREL IN NESTBOX}

During the summer of 1989 we eight pairs of Kestrels nesting on the and I strongly suspected a ninth as a was frequently in the vicinity of the $h$ and nearby garage. I looked in $w$ thought were all the possible places nest, but found nothing.

Then one day I heard a flutter of above my head, and, looking up, Is young kestrel taking its maiden across the yard and beyond it. Peerin of a small bird house, normally use House Sparrows was another $y$ kestrel.

It never occurred to me that a $k$ could get into that house so I mea: the opening and it was $17 / 8$ in. wid a curved arch beginning at $11 / 2$ ir height in the centre of $21 / 4 \mathrm{in}$. Ther no perch on the front of the house.

Inside measurements of the bird I are $63 / 4 \times 101 / 2$ in. I only saw the youngsters, but there could have some flying earlier. - Sig Jord White Bear, Saskatchewan.

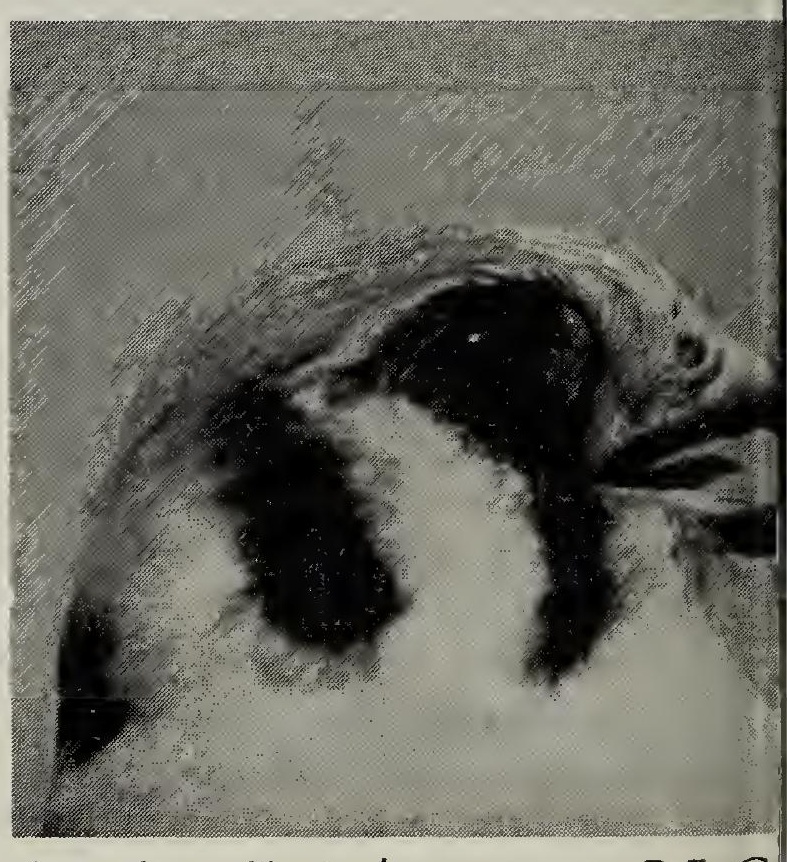

American Kestrel 


\section{THE OLD SHADE TREE}

Before Saskatchewan had a city, A village or a town,

When people dwelt in forts and tents,

And no settlers were around,

There was an interesting incident

Which happened not in vain

In a beautiful white spruce forest

Of the Red Deer River plain.

Grasping, struggling, reaching, striving,

Pushing, stretching, spreading, thriving,

A poplar began to grow.

It pushed up through the mighty evergreens, Struggling the light to see.

By the time of the Riel Rebellion,

The sapling became a tree.

But a fire swept hungrily through the plain,

And the spruce toppled down,

And there in a twisted ugly mess,

They lay rotting on the ground.

Rotting, shrinking, and abating,

Moulding and deteriorating;

But the poplar still did stand.

Among shrubbery, saplings, and alders,

This tree became a king;

And from its stretched leafy branches,

Many birds their songs would sing,

And perhaps beneath those leafy branches,

The moose and elk would roam,

And perchance some lonely Indian

Would set up his tented home;

Wandering, voyaging, tramping;

Traveling, tenting and camping;

And the poplar still did stand.

But a newly married homesteader came In nineteen twenty-eight,

And he built near the mighty poplar

A shack for he and his mate.

The homesteader busily cut trees down,

His yard from the brush to free,

But he did spare the mighty poplar,

And named it - "the old shade tree."

Chipping, chopping, clearing, scrubbing,

Cutting, trimming, slashing, grubbing,

But the shade tree still did stand.
And so it did stand for many a year, And watched the changing scene,

'Til the farmer's land was growing wh Where the poplars once had been;

'Til a rotted log meat house, which bene The old shade tree had stood,

Was at last torn down by the farmer, And was sawed up for fire-wood.

Tearing, breaking, prying, clawing, Wreaking, bucking, splitting, sawing. But the shade tree still did stand.

The farmer's twin sons became naturali And oft the cry would be

"Come look at the bird that is sitting, In the top of the old shade tree."

For many a weary migrant stopped the When through the land did roam, And in the trunk a noisy flicker Did carve out a hollow home. Picking, pecking, knocking, tapping, Drumming, hammering, and rapping But the shade tree still did stand.

The sons began the study of insects, Or entomology;

They collected many specimens, From the trunk of the old shade tree. For the under-wing moths to sugar bait ca And ants lived in the wood, And many beetles of various kinds, Feasted on the sap which flowed. Buprestids, and Elaterids, Tenebroinids, and Cucujids, But the shade tree still did stand.

And so the poplar continued to stand 'Til nineteen fifty-eight,

As the mighty undisputed king Of the homesteader's windbreak.

But then one stormy August afternoor A strong south wind did blow,

It stirred and shook the mighty shade $t$ And to the ground it did go.

Tumbling, toppling, dropping, crashi Falling, splintering and smashing. Gone - it took decades to grow.

- Ron Hooper, P.O. Box 757,

Qu'Appelle, Saskatchewan. SOG $1 S$ 